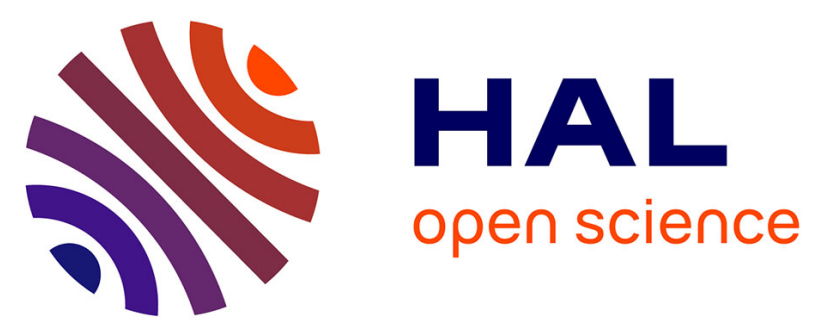

\title{
High negative genetic correlations between growth traits and wood properties suggest incorporating multiple traits selection including economic weights for the future Scots pine breeding programs
}

\author{
Zhou Hong, Anders Fries, Harry X. Wu
}

\section{To cite this version:}

Zhou Hong, Anders Fries, Harry X. Wu. High negative genetic correlations between growth traits and wood properties suggest incorporating multiple traits selection including economic weights for the future Scots pine breeding programs. Annals of Forest Science, 2014, 71 (4), pp.463-472.

10.1007/s13595-014-0359-3 . hal-01102222

\author{
HAL Id: hal-01102222 \\ https://hal.science/hal-01102222
}

Submitted on 12 Jan 2015

HAL is a multi-disciplinary open access archive for the deposit and dissemination of scientific research documents, whether they are published or not. The documents may come from teaching and research institutions in France or abroad, or from public or private research centers.
L'archive ouverte pluridisciplinaire HAL, est destinée au dépôt et à la diffusion de documents scientifiques de niveau recherche, publiés ou non, émanant des établissements d'enseignement et de recherche français ou étrangers, des laboratoires publics ou privés. 


\title{
High negative genetic correlations between growth traits and wood properties suggest incorporating multiple traits selection including economic weights for the future Scots pine breeding programs
}

\author{
Zhou Hong • Anders Fries • Harry X. Wu
}

Received: 24 September 2013 / Accepted: 12 January 2014 /Published online: 31 January 2014

(C) INRA and Springer-Verlag France 2014

\begin{abstract}
- Context The development of multiple trait selection indices for solid (structure) wood production in the Scots pine (Pinus sylvestris $\mathrm{L}$.) breeding program requires genetic variances and covariances estimated among wood quality traits including stiffness.

- Aims Genetic control and relationships among Scots pine growth, fiber, and wood quality traits were assessed by estimating heritability, phenotypic and genetic correlation using a Scots pine full-sib family trial.

- Method Wood quality traits including clearwood and dynamic acoustic stiffness were measured using SilviScan and Hitman in a 40-year-old progeny trial and by sampling increment cores of 778 trees of 120 families. Genetic parameters were estimated using the mixed model by the ASReml software.

- Results Heritability ranged from 0.147 to 0.306 for growth, earlywood, transition wood and latewood proportion traits and from 0.260 to 0.524 for fiber dimension, wood density, MFA
\end{abstract}

Handling Editor: Jean-Michel Leban

Contributions of the co-authors Zhou Hong's contribution includes field data collection, data analysis and the writing of the manuscript. Anders Fries coordinated the experiment design, data collection and contributed to the writing of the manuscript. Harry X. Wu initiated the project, designed sampling strategy and contributed to the writing of the manuscript. All authors read and approved the final manuscript.

Z. Hong $\cdot$ A. Fries $\cdot$ H. X. Wu

Umeå Plant Science Centre, Department Forest Genetics and Plant Physiology, Swedish University of Agricultural Sciences,

SE-90183 Umeå, Sweden

H. X. Wu $(\bowtie)$

CSIRO Plant Industry, GPO Box 1600, Canberra ACT 2601,

Australia

e-mail: harry.wu@slu.se

H. X. Wu

e-mail: Harry.wu@CSIRO.au and stiffness traits. The highly unfavorable genetic correlation between diameter and whole core density $(-0.479)$ and clearwood stiffness $(-0.506)$ and dynamic acoustic stiffness $(-0.382)$ was observed in this study.

- Conclusion The unfavorable genetic correlations between growth traits and stiffness indicate that multiple traits selection using optimal economic weights and optimal breeding strategies are recommended for the advanced Scots pine breeding program.

Keywords Heritability · Correlation · Genetic gain · Wood quality traits $\cdot$ Scots pine

\section{Introduction}

Scots pine (Pinus sylvestris L.) is the most widely distributed pine, native to Europe and northwestern Asia, ranging from Scotland, Ireland and Portugal in the west to Siberia and the Caucasus Mountains in the east and to far north as the Arctic Circle in Scandinavia countries (York and Littlefield 1942). Scots pine and Norway spruce (Picea abies (L.) Karst.) are the two most important commercial species for Swedish forestry. The Swedish Scots pine breeding program has implemented two cycles of selective breeding and established a third cycle of seed orchards with large genetic gains for growth-related traits (Rosvall 2011). The general objectives of the Swedish Scots pine breeding program are to balance efficient improvement of high-valued economic traits and adequate genetic variation. Open-pollinated seed orchards are widely implemented for deployment purpose, and breeding values for vitality, growth and wood quality traits are predicted for selection purposes (Berlin 2009).

Wood quality traits (e.g. wood density, stiffness) were not included as the selection criteria and breeding objective traits 
in the first two cycles of selective breeding program for Scots pine. As Scots pine breeding program progresses further, improvement of wood quality traits is becoming an important issue due to highly negative genetic correlations between growth and wood density observed in the species and breeding experience in other pine species (Fries and Ericsson 2006; Hannrup et al. 2000). Wood density has been regarded as one of the most important factors affecting wood properties such as stiffness, strength and shrinkage behavior and was used by many breeding programs as an initial wood quality trait for improvement. However, it has been shown both experimentally and theoretically (Cave 1976) that microfibril angle (MFA) is at least as important as density for the prediction of the strength and stiffness of solid wood. To include MFA and stiffness in the breeding program, a rapid, cost-effective method to measure a large number of sample trees from progeny tests is required. SilviScan has become a commonly used technique for detailed measurement of radial variations in wood density and MFA and the estimation of stiffness (e.g. modulus of elasticity-MOE) using increment cores (Evans 2006), and genetic parameters were estimated using SilviScan data in many conifer species including radiata pine (Pinus radiata, Baltunis et al. 2007), Douglas fir (Pseudotsuga menziesii, Lachenbruch et al. 2010; Vikram et al. 2011) and white spruce (Picea glauca, Lenz et al. 2010, 2011).

To include wood quality traits into selection and breeding program, genetic variance and covariance are required for breeding value prediction and for designing optimal breeding strategy (mating and selection strategy). Genetic parameters for growth and wood properties have been estimated for Scots pine. The heritability for stem diameter $\left(h^{2}=0.10-0.30\right)$ is usually lower than that for tree height $\left(h^{2}=0.25-0.32\right)$ in Scots pine (Hannrup and Ekberg 1998; Hannrup et al. 2000, 2001). For wood properties, the main focus has so far been on wood density (Fries and Ericsson 2009) with a few estimates on tracheid length and heartwood properties. Heritability for wood density was estimated relatively high based on the whole core $\left(h^{2}=0.57\right.$, Velling 1974) and slightly lower based on separate annual rings or annual ring components (earlywood or latewood) (Fries and Ericsson 2006, 2009; Hannrup and Ekberg 1998; Hannrup et al. 2000) or estimated by the pilodyn method $\left(h^{2}=0.10-0.50\right.$, Haapanen et al. 1997). Furthermore, heritability from 0.30 to 0.50 was estimated for fiber length, fiber width and fiber angle for Scots pine (Ericsson and Fries 2004; Hallingbäck 2010; Hannrup and Ekberg 1998,). Nearly all estimated genetic correlations between growth traits and wood density were negative $r_{A}=-0.14$ to -0.4 for height and wood density (Fries and Ericsson 2006, 2009; Hannrup et al. 2000) and $r_{A}=-0.42$ to -0.5 for stem diameter and wood density (Fries and Ericsson 2006, 2009). Fiber length was also negatively correlated with growth traits $r_{A}=-0.12$ for height and $r_{A}=-0.63$ for stem diameter, respectively (Ericsson and Fries 2004). In contrast, fiber width was positively correlated with growth $\left(r_{A}=0.56\right.$ for height and $r_{A}=$ 0.90 for stem diameter, respectively).

In this paper, genetic parameters for wood quality related traits, e.g., fiber dimension, wood density, earlywood and latewood proportion as well as for MFA, clearwood stiffness and dynamic acoustic stiffness of the standing trees are estimated for Swedish Scots pine. The objectives in this study were to (1) estimate genetic variation and heritability for growth, fiber and wood quality traits including stiffness; (2) estimate the genetic correlations between these growth, fiber and wood quality traits; (3) evaluate the possibility to use nondestructive acoustic testing techniques to predict stiffness of clearwood for Scots pine; and (4) estimate genetic gain for volume and stiffness from simple mass selection.

\section{Material and method}

\subsection{The field test}

The study was undertaken using a full-sib diallel progeny test located at $100-\mathrm{km}$ northwest of Örnsköldsvik in Northern

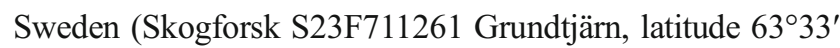
$\mathrm{N}$; Longitude $17^{\circ} 25^{\prime} \mathrm{E}$; altitude 320 m.a.s.l.). The trial was planted on an undulated sandy moraine with gradual sloping facing west in September 1971. A single tree plot at 2.2-m square spacing with 179 full-sib families, generated from a partial diallel mating of 40 plus trees was planted on a 3.5-ha block. A completely randomized design with 40 trees each family was used. The 40 plus trees were selected from the first generation parents. In September 2011, the trees were 40 years old, and about $43 \%$ of the planted trees had left after the first thinning and mortality. Approximately five trees from 120 families and two trees from the remaining families were sampled giving a total of 778 sample trees for the study.

\subsection{Growth data}

The 778 sample trees were measured for tree height (HGT) and breast height diameter (DBH) at 40 years of tree age. Stem volume (VOL, $\left.\mathrm{dm}^{3}\right)$ was calculated as a function of diameter at breast height (DBH, $\mathrm{cm}$ ) and height (HGT, $\mathrm{m}$ ) according to the following equations for trees $>5 \mathrm{~cm}$ in diameter (Brandel 1990): $\mathrm{VOL}=\exp [-2.7841+1.9474 \cdot \ln (\mathrm{DBH})-0.05947$. $\ln (\mathrm{DBH}+20)+1.40958 \cdot \ln (\mathrm{HGT})-0.4581 \cdot \ln (\mathrm{HGT}-1.3)]$.

\subsection{Hitman ST300 predicted modulus of elasticity ( $\left.\mathrm{MOE}_{\mathrm{tof}}\right)$}

Standing-tree acoustic velocity was measured by hammering two sensor probes (transmitting and receiving probes) around breast height (1.3 m from the ground) into the stem. A stress wave was induced by striking the transmitting probe with a steel hammer, and the time-of-flight (TOF) was recorded. The 
Hitman ST300 measurements were taken on the southeast side of the tree, and two series of eight hits gave two values of which the average was used. Distance between the measurement points was $0.7-1.3 \mathrm{~m}$ (distances below $0.8 \mathrm{~m}$ were not very common). If the two velocities differed more than $0.1 \mathrm{~m} / \mathrm{ms}$, additional series were taken to get a satisfactorily precision. The standing tree time-of-flight technique provided an acoustic wave velocity for the stem. Modulus of elasticity using time-offlight $\left(\mathrm{MOE}_{\mathrm{tof}}\right)$ was related to the acoustic velocity of the wood according to the following equation: $\mathrm{MOE}_{\text {tof }}=$ $\mathrm{V}^{2} \times \mathrm{D} / 10^{9}$, where, $\mathrm{V}=$ Velocity $(\mathrm{m} / \mathrm{s}) \quad(\mathrm{V}=1 / \mathrm{T} ; \mathrm{T}=$ timeof-flight (s)), $\mathrm{D}=$ Green density $\left(\mathrm{kg} / \mathrm{m}^{3}\right)$ (Bucur 2006).

\subsection{SilviScan analysis for wood and fiber traits}

Increment cores at breast height were taken from 778 trees for SilviScan measurement. The SilviScan instrument (Innventia $\mathrm{AB}$, Stockholm, Sweden) is an instrument designed to analyze wood and fiber traits in radial strip samples measuring 2-mm thick and 7-mm high. The sampled strips for this study were prepared from increment cores (diameter $10 \mathrm{~mm}$ ) taken through the stem from bark to bark with a normal increment borer run by an electric boring machine. Each sample was soaked in clean acetone to remove extractives to avoiding disturbances of the measurement. The specimens were conditioned in the laboratory at approximately $23{ }^{\circ} \mathrm{C}$ and $43 \%$ relative humidity and then scanned from pith-to-bark for wood and fiber traits using X-ray densitometry and X-ray diffractometry. From the obtained data, wood properties such as fiber wall thickness (FWT), fiber width in the radial direction (FRW) and in the tangential direction (FTW), fiber coarseness (FMC), microfibril angle (MFA) and clearwood modulus of elasticity $\left(\mathrm{MOE}_{\mathrm{s}}\right)$ are estimated (Evans 2006). Earlywood was then defined as the first part of the ring with wood density changing from the minimum up to $20 \%$ variation from the minimum within the ring. Latewood was defined as the part of ring with the highest density with $20 \%$ of the variation, and transition wood was defined as the middle of the ring occupying $60 \%$ variation (e.g., from 20 to $80 \%$ of range in variation). Proportion of earlywood (EWP), transition wood (TWP) and latewood width (LWP) and wood density of earlywood (EWD), transition wood (TWD) and latewood (LWD) were also calculated.

\subsection{Area-weighted average data}

The variation of wood quality trait was analyzed at whole core level and for each annual ring component (earlywood, transition wood and latewood, respectively). Area-weighted values were calculated and utilized in the study since areaweighted average was more accurate to represent the average properties of the wood in a $\log$ (Gräns et al.
2009). The area-weighted values of the cores and the segments were calculated as

$A B=\sum(a i \times d i) / \sum a i$

where $\mathrm{AB}$ was the ring area-weighted value, $\alpha i$ was the crosssectional area of the ith annual ring assuming that each ring was circular and $d i$ is the value of the ith annual ring (Hannrup et al. 2000).

\subsection{Statistical analysis}

Data analyses for Swedish trials were usually conducted using post-blocking for the completely randomly design in the past and using spatial analyses of the adjustment in the recent. However, due to irregular distribution of sampled trees after thinning in the current study, these adjustments are not efficient (Fries and Ericsson 2006); therefore, the data were analyzed using the following model by the ASReml statistical software package (Gilmour et al. 2009) for individual and multivariate traits:

$\mathrm{y}_{i j k}=\mu+\mathrm{G}_{i}+\mathrm{G}_{j}+\mathrm{S}_{i j}+\mathrm{E}_{i j k}$

where, $y_{i j k}$ is the $k$ th observation for the $i{ }^{\text {th }}$ cross; $\mu$ is the overall mean; $\mathrm{G}_{i}, \mathrm{G}_{j}$ is the random general combining ability (GCA) effect of the ith female or the $j$ th male normally, independently distributed (NID) $\left(0, \sigma_{\mathrm{G}}^{2}\right), i, j=1$ to $\mathrm{p}$ and $i<j$; $\mathrm{S}_{i j}$ is the random specific combining ability (SCA) effect of the $i$ th and the $j$ th parents $(i \neq j) \sim \operatorname{NID}\left(0, \sigma^{2} \mathrm{~S}\right) ; \mathrm{E}_{i j k}$ is the random error term $\sim \operatorname{NID}\left(0, \sigma_{E}^{2}\right)$.

Estimates of heritability were obtained for each trait using the variance components from the GCA and SCA model. Standard errors were estimated using Taylor expansion as described in ASReml package.

Individual-tree narrow-sense heritability $h^{2}=\frac{\sigma_{A}^{2}}{\sigma_{p}^{2}}=$ $\frac{4 \sigma_{G}^{2}{ }_{G}}{2 \sigma^{2}{ }_{G}+\sigma^{2}{ }_{s}+\sigma_{e}^{2}}$ where $\sigma_{A}^{2}$ : additive genetic variance; $\sigma_{p}^{2}$ : phenotypic variance; $\sigma_{G}^{2}$ : general combining ability variance; $\sigma_{s}^{2}$ : specific combining ability variance; $\sigma_{e}^{2}$ : residual variance.

Variances are not independent of the scale and the mean of the respective traits (Sokal and Rohlf 1995). Therefore, to relatively compare phenotypic and additive genetic variation of the different traits, a parameter measuring the coefficient of variation was calculated using variance and mean $\left(C V_{A}\right.$ and $C V_{A}$, respectively).

Genetic correlations between traits $\mathrm{x}$ and $\mathrm{y}$ were obtained from the estimated additive genetic covariance and variance components (using the individual tree model) as

$r_{A}=\frac{\sigma_{A_{x} A_{Y}}}{\sigma_{A_{x}} \sigma_{A_{y}}}$ 
where $\sigma_{A_{x} A_{y}}$ is the additive genetic covariance component between traits $\mathrm{x}$ and $\mathrm{y}$ and $\sigma_{A_{x}}^{2}$, and $\sigma_{A_{y}}^{2}$ is the additive genetic variance component for traits $\mathrm{x}$ and $\mathrm{y}$, respectively.

In the Swedish Scots pine program, volume and stemwood quality (stiffness) are two important breeding objective traits (Berlin 2009; Fries 2012). Genetic gains were calculated to improve these two traits $\left(\mathrm{VOL}, \mathrm{MOE}_{\mathrm{s}}\right.$ or $\mathrm{MOE}_{\text {tof }}$ ) by direct selection and indirect selection using correlated traits. The genetic gain expressed as the percentage of the mean in direct selection for trait $i$ was estimated as

$\Delta G_{i}=\frac{i \times h_{i}^{2} \times \sigma_{p}(i)}{M v_{i}} \times 100$

where $i$ is the selection intensity, $h_{i}^{2}$ is the individual-tree narrow-sense heritability, $\sigma_{p}(i)$ is the phenotypic standard deviation and $M v_{i}$ is the mean value of trait (Falconer and Mackay 1996). The genetic gain of target trait $t$ from indirect selection of correlated trait $i$ was estimated using

$\Delta G_{t}=\frac{i h_{t} h_{i} r_{A} \sigma_{p t}}{M v_{t}} \times 100$

where $h_{t}$ is the square root of heritability for target trait, $r_{A}$ is the additive genetic correlation between selection trait $i$ and target trait $t$ and $\sigma_{p t}$ is the phenotypic standard deviation for target trait $t$.

\section{Result}

3.1 Mean values and the size of variation for growth, fiber and wood quality traits

The average, minimum and maximum value, genetic and phenotypic standard deviation and coefficients of variation for growth, fiber and wood quality traits were presented in Table 1 . The average of DBH was $19.6 \mathrm{~cm}$ for 40 years Scots pine, translating into about $0.5 \mathrm{~cm}$ per year growth rate. On average, earlywood had the highest proportion (55.2\%), and latewood had the least proportion (15.3\%). Scots pine has a relatively high wood density $\left(447 \mathrm{~kg} / \mathrm{m}^{3}\right)$ and with a low earlywood density $\left(331 \mathrm{~kg} / \mathrm{m}^{3}\right)$ and a high latewood density $\left(763 \mathrm{~kg} / \mathrm{m}^{3}\right)$. The average MFA of Scots pine was also relatively low at $17.3^{\circ}$.

Genetic coefficients of variation $\left(C V_{A}\right)$ varied between 2.34 and $16.6 \%$, with the highest coefficients for volume of individual tree. Among the three wood proportion traits, the latewood proportion had the largest $C V_{A}(7.25 \%)$ even though it had the lowest average of $15.3 \%$. All other wood quality traits had low $C V_{A}$ from 2.34 to $5.71 \%$ with three exceptions (e.g. MFA $12.5 \%, \mathrm{MOE}_{\mathrm{s}} 11.1 \%$ and $\mathrm{MOE}_{\text {tof }} 13.6 \%$ ). The average clearwood stiffness from SilviScan $\left(\mathrm{MOE}_{\mathrm{s}}\right)$ is significantly higher than the acoustic $\mathrm{MOE}_{\text {tof }}$ for the population.

\subsection{Heritability of growth, fiber and wood quality traits}

Heritability for the growth traits (DBH, HGT and VOL) was between 0.238 and 0.273 , and for wood proportion traits, it was slightly lower with an exception of a higher heritability of 0.306 for the latewood proportion (Table 1 ). The heritability for the wood and fiber quality traits was higher than growth traits, ranging from 0.260 (FTW) to 0.524 (FMC) and was around 0.400 for most of the wood quality traits.

\subsection{Correlations among growth traits}

Earlywood proportion was positively additive genetic correlated with all three growth traits $(0.427,0.320$ and 0.295 for DBH, HGT and VOL, respectively), while transition and latewood proportion were negatively additive genetic correlated with these same growth traits (Table 2). As expected, correlations among the wood proportion percentage are all negative (for example, genetic correlation was -0.514 between EWP and LWP).

\subsection{Correlations among fiber and wood quality traits}

Genetic correlations were high among the four wood density traits $\left(r_{A} \geq 0.764\right)$ but high to low with the fiber dimension traits $\left(0.909 \geq r_{A} \geq-0.0701\right.$, Table 3$)$. Two fiber dimension traits (FRW and FTW) had low and non-significant genetic correlations with wood density traits $\left(0.125 \geq r_{A} \geq-0.248\right)$, while fiber wall thickness and coarseness had high and positive correlations with wood density traits $\left(0.909 \geq r_{A} \geq 0.544\right)$ reflecting fiber wall thickness contributing to the overall wood density. This indicates that it is the fiber cell wall thickness rather than the size of the fiber cell contributing to wood density. MFA was highly but negatively correlated with all wood density traits as expected $\left(-0.522 \geq r_{A} \geq-0.781\right)$, while MFA had negative but non-significant genetic correlations with the two fiber dimension traits (Table 3). As expected, genetic correlation between two stiffness measurements $\left(\mathrm{MOE}_{\mathrm{s}}\right.$ and $\left.\mathrm{MOE}_{\mathrm{tof}}\right)$ was very high (0.945), and stiffness had high and positive genetic correlations with all wood density traits $\left(0.904 \geq r_{A} \geq 0.760\right)$ and with FWT and FMC. Similarly, stiffness had high negative genetic correlation with MFA as expected $\left(-0.911\right.$ and -0.831 for $\mathrm{MOE}_{\mathrm{s}}$ and $\mathrm{MOE}_{\mathrm{tof}}$, respectively) but had low and non-significant correlations with two fiber dimension traits. The phenotypic correlations for among-trait groups and within-trait group are similar to genetic correlations but usually slightly lower than the genetic correlations.

3.5 Correlation between growth, fiber and wood quality traits

Growth traits (DBH, HGT and VOL) all had negative genetic correlations with the four wood density traits (DEN, EWD, 
Table 1 The average, range, genetic $\left(\sigma_{\mathrm{a}}\right)$ and phenotypic $\left(\sigma_{\mathrm{P}}\right)$ standard deviations, genetic $\left(C V_{A}\right)$ and phenotypic $\left(C V_{P}\right)$ coefficients of variation, and narrow-sense heritability $\left(h^{2}\right)$ for the six growth, fiber, and 11 wood quality traits (standard errors for $h^{2}$ presented within the parenthesis)

\begin{tabular}{|c|c|c|c|c|c|c|c|c|}
\hline Trait & Min & Max & Mean & $\sigma_{\mathrm{a}}$ & $C V_{A}(\%)$ & $\sigma_{\mathrm{P}}$ & $C V_{p}(\%)$ & $h^{2}$ \\
\hline \multicolumn{9}{|c|}{ Wood quantity traits } \\
\hline $\mathrm{DBH}(\mathrm{mm})$ & 82.0 & 314 & 196 & 15.0 & 7.65 & 30.8 & 15.7 & $0.238(0.0791)$ \\
\hline HGT (dm) & 102 & 196 & 162 & 7.07 & 4.36 & 13.5 & 8.33 & $0.273(0.0883)$ \\
\hline $\operatorname{VOL}\left(\mathrm{dm}^{3}\right)$ & 46.0 & 746 & 332 & 55.1 & 16.6 & 112 & 33.8 & $0.243(0.0844)$ \\
\hline EWP (\%) & 36.1 & 67.2 & 55.2 & 1.85 & 3.35 & 4.43 & 8.02 & $0.174(0.0572)$ \\
\hline TWP (\%) & 18.2 & 45.3 & 29.5 & 1.60 & 5.42 & 4.17 & 14.1 & $0.147(0.0653)$ \\
\hline LWP (\%) & 9.21 & 22.8 & 15.3 & 1.11 & 7.25 & 2.01 & 13.1 & $0.306(0.0954)$ \\
\hline \multicolumn{9}{|c|}{ Wood and fiber quality traits } \\
\hline $\operatorname{DEN}\left(\mathrm{kg} / \mathrm{m}^{3}\right)$ & 364 & 597 & 447 & 20.1 & 4.50 & 31.2 & 6.98 & $0.417(0.100)$ \\
\hline $\operatorname{EWD}\left(\mathrm{kg} / \mathrm{m}^{3}\right)$ & 280 & 410 & 331 & 12.8 & 3.87 & 20.4 & 6.16 & $0.399(0.101)$ \\
\hline TWD $\left(\mathrm{kg} / \mathrm{m}^{3}\right)$ & 376 & 660 & 497 & 21.9 & 4.41 & 34.1 & 6.86 & $0.417(0.102)$ \\
\hline $\operatorname{LWD}\left(\mathrm{kg} / \mathrm{m}^{3}\right)$ & 590 & 905 & 763 & 33.6 & 4.40 & 50.1 & 6.57 & $0.449(0.101)$ \\
\hline FRW $(\mu \mathrm{m})$ & 16.9 & 38.4 & 33.4 & 1.08 & 3.23 & 1.62 & 4.85 & $0.449(0.111)$ \\
\hline FTW $(\mu \mathrm{m})$ & 14.0 & 35.5 & 28.6 & 0.67 & 2.34 & 1.31 & 4.58 & $0.260(0.0891)$ \\
\hline FWT $(\mu \mathrm{m})$ & 1.22 & 3.36 & 2.45 & 0.13 & 5.31 & 0.191 & 7.80 & $0.438(0.110)$ \\
\hline FMC $(\mu \mathrm{g} / \mathrm{m})$ & 202 & 522 & 405 & 23.1 & 5.71 & 32.0 & 7.90 & $0.524(0.117)$ \\
\hline $\operatorname{MFA}\left({ }^{\circ}\right)$ & 7.77 & 36.7 & 17.3 & 2.17 & 12.5 & 4.22 & 24.4 & $0.264(0.0791)$ \\
\hline $\mathrm{MOE}_{\mathrm{s}}(\mathrm{Gpa})$ & 2.77 & 15.9 & 10.2 & 1.14 & 11.1 & 1.86 & 18.2 & $0.377(0.101)$ \\
\hline $\mathrm{MOE}_{\text {tof }}(\mathrm{Gpa})$ & 3.44 & 11.2 & 6.68 & 0.91 & 13.6 & 1.36 & 20.3 & $0.447(0.104)$ \\
\hline
\end{tabular}

$D B H$ diameter at breast height, $H G T$ tree height, $V O L$ stem volume of individual tree, $E W P$ earlywood width proportion, $T W P$ transition wood width proportion, $L W P$ latewood width proportion, $D E N$ area-weighted mean wood density, $E W D$ area-weighted earlywood density, $T W D$ area-weighted transition wood density, $L W D$ area-weighted latewood density (densities from SilviScan measurements), $F R W$ fiber width in the radial direction in the stem, $F T W$ fiber width in the tangential direction in the stem, $F W T$ fiber wall thickness, $F M C$ fiber coarseness, $M F A$ microfibril angle, $M O E_{S}$ modulus of elasticity estimated using SilviScan-3, $M O E_{\text {tof }}$ modulus of elasticity estimated using VEL and DEN

TWD and LWD), fiber wall thickness (FWT), fiber coarseness (FMC) and the two stiffness traits (Table 4). However, negative correlations between growth traits and whole core and earlywood density and stiffness were moderately strong $\left(-0.235 \geq r_{A} \geq-0.524\right)$, while negative correlations between growth traits and transition and latewood density, fiber wall thickness and fiber coarseness were generally low $(-0.0801 \geq$ $\left.r_{A} \geq-0.356\right)$. Genetic correlations between the ring width proportion traits (EWP, TWP and LWP) and their corresponding densities (EWD, TWD and LWD) were all positive with an increasing trend from earlywood to latewood (e.g. from 0.102 to 0.615 ). Earlywood proportion had low and non-significant genetic correlations with three wood densities (DEN, TWD and LWD), while transition wood had slightly higher but negative genetic correlation with three other wood densities (DEN, EWD and LWD). However, latewood proportion had higher and positive genetic correlation with all four wood densities (0.615 $\left.\geq r_{A} \geq 0.274\right)$. Growth traits (DBH, HGT and

Table 2 Additive genetic (above diagonal) and phenotypic (below diagonal) correlations between growth traits (standard errors within the parenthesis)

\begin{tabular}{|c|c|c|c|c|c|c|}
\hline & \multicolumn{3}{|l|}{ Growth traits } & \multicolumn{3}{|l|}{ Ring width traits } \\
\hline & $\mathrm{DBH}$ & HGT & VOL & EWP & TWP & LWP \\
\hline DBH & 1 & $0.620(0.155)$ & $0.980(0.00843)$ & $0.427(0.249)$ & $-0.0621(0.290)$ & $-0.631(0.170)$ \\
\hline HGT & $0.557(0.0301)$ & 1 & $0.681(0.0841)$ & $0.320(0.263)$ & $-0.133(0.292)$ & $-0.366(0.224)$ \\
\hline VOL & $0.876(0.00815)$ & $0.450(0.0271)$ & 1 & $0.295(0.142)$ & $-0.0831(0.131)$ & $-0.487(0.117)$ \\
\hline EWP & $0.024(0.0412)$ & $-0.0221(0.0458)$ & $-0.0322(0.0278)$ & 1 & $-0.798(0.102)$ & $-0.514(0.209)$ \\
\hline TWP & $0.100(0.0443)$ & $0.0558(0.0454)$ & $0.0411(0.0248)$ & $-0.894(0.00921)$ & 1 & $-0.396(0.0651)$ \\
\hline LWP & $-0.262(0.0421)$ & $-0.0721(0.0482)$ & $-0.170(0.0309)$ & $-0.355(0.0401)$ & $-0.103(0.045)$ & 1 \\
\hline
\end{tabular}


Table 3 Additive genetic (above diagonal) and phenotypic (below diagonal) correlations between wood and fiber quality traits (standard errors within the parenthesis)

\begin{tabular}{|c|c|c|c|c|c|c|c|c|c|c|c|}
\hline & \multicolumn{4}{|c|}{ Wood density traits } & \multicolumn{5}{|c|}{ Fiber dimension traits } & \multicolumn{2}{|c|}{ Stiffness traits } \\
\hline & DEN & EWD & TWD & LWD & FRW & FTW & FWT & MFC & MFA & $\mathrm{MOE}_{\mathrm{s}}$ & $\mathrm{MOE}_{\text {tof }}$ \\
\hline DEN & 1 & $\begin{array}{l}0.856 \\
(-0.0591)\end{array}$ & $\begin{array}{l}0.931 \\
(0.0282)\end{array}$ & $\begin{array}{l}0.923 \\
(0.0368)\end{array}$ & $\begin{array}{l}0.121 \\
(0.205)\end{array}$ & $\begin{array}{l}-0.183 \\
(0.229)\end{array}$ & $\begin{array}{l}0.773 \\
(0.123)\end{array}$ & $\begin{array}{l}0.585 \\
(0.127)\end{array}$ & $\begin{array}{l}-0.556 \\
(0.170)\end{array}$ & $\begin{array}{l}0.843 \\
(0.0778)\end{array}$ & $\begin{array}{l}0.872 \\
(0.0644)\end{array}$ \\
\hline EWD & $\begin{array}{l}0.843 \\
(0.0168)\end{array}$ & 1 & $\begin{array}{l}0.764 \\
(0.0848)\end{array}$ & $\begin{array}{l}0.836 \\
(0.0681)\end{array}$ & $\begin{array}{l}0.0342 \\
(0.214)\end{array}$ & $\begin{array}{l}-0.248 \\
(0.226)\end{array}$ & $\begin{array}{l}0.771 \\
(0.0889)\end{array}$ & $\begin{array}{l}0.544 \\
(0.142)\end{array}$ & $\begin{array}{l}-0.781 \\
(0.134)\end{array}$ & $\begin{array}{l}0.862 \\
(0.0545)\end{array}$ & $\begin{array}{l}0.904 \\
(0.0591)\end{array}$ \\
\hline TWD & $\begin{array}{l}0.820 \\
(0.0161)\end{array}$ & $\begin{array}{l}0.693 \\
(0.0268)\end{array}$ & 1 & $\begin{array}{l}0.930 \\
(0.0301)\end{array}$ & $\begin{array}{l}0.0334 \\
(0.208)\end{array}$ & $\begin{array}{l}-0.0701 \\
(0.232)\end{array}$ & $\begin{array}{l}0.909 \\
(0.0445)\end{array}$ & $\begin{array}{l}0.659 \\
(0.109)\end{array}$ & $\begin{array}{l}-0.593 \\
(0.160)\end{array}$ & $\begin{array}{l}0.805 \\
(0.0856)\end{array}$ & $\begin{array}{l}0.816 \\
(0.0801)\end{array}$ \\
\hline LWD & $\begin{array}{l}0.650 \\
(0.0241)\end{array}$ & $\begin{array}{l}0.544 \\
(0.0319)\end{array}$ & $\begin{array}{l}0.703 \\
(0.0218)\end{array}$ & 1 & $\begin{array}{l}0.125 \\
(0.182)\end{array}$ & $\begin{array}{l}-0.213 \\
(0.199)\end{array}$ & $\begin{array}{l}0.893 \\
(0.0522)\end{array}$ & $\begin{array}{l}0.646 \\
(0.109)\end{array}$ & $\begin{array}{l}-0.522 \\
(0.146)\end{array}$ & $\begin{array}{l}0.760 \\
(0.0845)\end{array}$ & $\begin{array}{l}0.848 \\
(0.0645)\end{array}$ \\
\hline FRW & $\begin{array}{l}0.269 \\
(0.0532)\end{array}$ & $\begin{array}{l}-0.258 \\
(0.0528)\end{array}$ & $\begin{array}{l}-0.189 \\
(0.0548)\end{array}$ & $\begin{array}{l}-0.100 \\
(0.0552)\end{array}$ & 1 & $\begin{array}{l}0.407 \\
(0.199)\end{array}$ & $\begin{array}{l}0.264 \\
(0.201)\end{array}$ & $\begin{array}{l}0.647 \\
(0.122)\end{array}$ & $\begin{array}{l}-0.169 \\
(0.224)\end{array}$ & $\begin{array}{l}0.0733 \\
(0.215)\end{array}$ & $\begin{array}{l}0.0111 \\
(0.210)\end{array}$ \\
\hline FTW & $\begin{array}{l}-0.152 \\
(0.0465)\end{array}$ & $\begin{array}{l}-0.199 \\
(0.0461)\end{array}$ & $\begin{array}{l}-0.104 \\
(0.0447)\end{array}$ & $\begin{array}{l}-0.103 \\
(0.0462)\end{array}$ & $\begin{array}{l}0.492 \\
(0.0401)\end{array}$ & 1 & $\begin{array}{l}0.157 \\
(0.233)\end{array}$ & $\begin{array}{l}0.523 \\
(0.165)\end{array}$ & $\begin{array}{l}-0.0556 \\
(0.254)\end{array}$ & $\begin{array}{l}-0.0811 \\
(0.238)\end{array}$ & $\begin{array}{l}-0.292 \\
(0.222)\end{array}$ \\
\hline FWT & $\begin{array}{l}0.663 \\
(0.0139)\end{array}$ & $\begin{array}{l}0.740 \\
(0.0239)\end{array}$ & $\begin{array}{l}0.749 \\
(0.0191)\end{array}$ & $\begin{array}{l}0.609 \\
(0.0285)\end{array}$ & $\begin{array}{l}0.139 \\
(0.0552)\end{array}$ & $\begin{array}{l}0.273 \\
(0.0478)\end{array}$ & 1 & $\begin{array}{l}0.886 \\
(0.0444)\end{array}$ & $\begin{array}{l}-0.600 \\
(0.170)\end{array}$ & $\begin{array}{l}0.614 \\
(0.0933)\end{array}$ & $\begin{array}{l}0.770 \\
(0.0971)\end{array}$ \\
\hline MFC & $\begin{array}{l}0.493 \\
(0.0419)\end{array}$ & $\begin{array}{l}0.439 \\
(0.0441)\end{array}$ & $\begin{array}{l}0.453 \\
(0.0409)\end{array}$ & $\begin{array}{l}0.378 \\
(0.0431)\end{array}$ & $\begin{array}{l}0.468 \\
(0.0431)\end{array}$ & $\begin{array}{l}0.507 \\
(0.0378)\end{array}$ & $\begin{array}{l}0.789 \\
(0.0122)\end{array}$ & 1 & $\begin{array}{l}-0.515 \\
(0.181)\end{array}$ & $\begin{array}{l}0.614 \\
(0.143)\end{array}$ & $\begin{array}{l}0.543 \\
(0.150)\end{array}$ \\
\hline MFA & $\begin{array}{l}-0.207 \\
(0.0458)\end{array}$ & $\begin{array}{l}-0.255 \\
(0.0432)\end{array}$ & $\begin{array}{l}-0.276 \\
(0.0424)\end{array}$ & $\begin{array}{l}-0.382 \\
(0.0378)\end{array}$ & $\begin{array}{l}0.0789 \\
(0.0511)\end{array}$ & $\begin{array}{l}0.0256 \\
(0.0467)\end{array}$ & $\begin{array}{l}-0.181 \\
(0.0478)\end{array}$ & $\begin{array}{l}-0.299 \\
(0.0522)\end{array}$ & 1 & $\begin{array}{l}-0.911 \\
(0.0411)\end{array}$ & $\begin{array}{l}-0.831 \\
(0.0863)\end{array}$ \\
\hline $\mathrm{MOE}_{\mathrm{s}}$ & $\begin{array}{l}0.552 \\
(0.0330)\end{array}$ & $\begin{array}{l}0.541 \\
(0.0341)\end{array}$ & $\begin{array}{l}0.527 \\
(0.0323)\end{array}$ & $\begin{array}{l}0.517 \\
(0.0248)\end{array}$ & $\begin{array}{l}-0.202 \\
(0.0544)\end{array}$ & $\begin{array}{l}-0.125 \\
(0.0494)\end{array}$ & $\begin{array}{l}0.481 \\
(0.0389)\end{array}$ & $\begin{array}{l}0.283 \\
(0.0504)\end{array}$ & $\begin{array}{l}-0.891 \\
(0.00891)\end{array}$ & 1 & $\begin{array}{l}0.945 \\
(0.0354)\end{array}$ \\
\hline $\mathrm{MOE}_{\text {tof }}$ & $\begin{array}{l}0.629 \\
(0.0301)\end{array}$ & $\begin{array}{l}0.619 \\
(0.0311)\end{array}$ & $\begin{array}{l}0.566 \\
(0.0332)\end{array}$ & $\begin{array}{l}0.596 \\
(0.03109)\end{array}$ & $\begin{array}{l}-0.213 \\
(0.0551)\end{array}$ & $\begin{array}{l}-0.105 \\
(0.0511)\end{array}$ & $\begin{array}{l}0.565 \\
(0.0356)\end{array}$ & $\begin{array}{l}0.356 \\
(0.0489)\end{array}$ & $\begin{array}{l}-0780 \\
(0.0311)\end{array}$ & $\begin{array}{l}0.755 \\
(0.0211)\end{array}$ & 1 \\
\hline
\end{tabular}

VOL) had positive and low genetic correlations with two fiber dimension traits (FRW and FTW) and MFA but negative correlations with other two fiber dimension traits (FWT and FMC).
Among genetic correlations between ring width proportion traits and fiber dimension traits, two correlations (e.g. 0.482 between EWP and FRW and 0.544 between LWP and FWT) are moderate to high. It also seems that stiffness traits are more

Table 4 Genetic correlation between growth, fiber and wood quality traits (standard errors within the parenthesis)

\begin{tabular}{|c|c|c|c|c|c|c|c|c|c|c|c|c|}
\hline & & \multicolumn{4}{|c|}{ Density trait } & \multicolumn{5}{|c|}{ Fiber dimensions trait } & \multicolumn{2}{|c|}{ Stiffness trait } \\
\hline & & DEN & EWD & TWD & LWD & FRW & FTW & FWT & MFC & MFA & $\mathrm{MOE}_{\mathrm{s}}$ & $\mathrm{MOE}_{\text {tof }}$ \\
\hline \multirow{6}{*}{$\begin{array}{c}\text { Growth } \\
\text { traits }\end{array}$} & $\mathrm{DBH}$ & -0.479 & -0.524 & -0.248 & -0.237 & 0.111 & 0.235 & -0.353 & -0.177 & 0.340 & -0.506 & -0.382 \\
\hline & & $(0.190)$ & $(0.074)$ & $(0.217)$ & $(0.193)$ & $(0.228)$ & $(0.252)$ & $(0.216)$ & $(0.220)$ & $(0.221)$ & $(0.181)$ & $(0.196)$ \\
\hline & HGT & -0.378 & -0.430 & -0.178 & -0.310 & 0.0178 & 0.290 & -0.292 & -0.204 & 0.310 & -0.448 & -0.323 \\
\hline & & $(0.208)$ & $(0.202)$ & $(0.224)$ & $(0.188)$ & $(0.235)$ & $(0.250)$ & $(0.205)$ & $(0.219)$ & $(0.229)$ & $(0.200)$ & $(0.210)$ \\
\hline & VOL & -0.395 & -0.355 & -0.111 & -0.126 & 0.0967 & 0.182 & -0.356 & -0.0801 & 0.239 & -0.370 & -0.235 \\
\hline & & $(0.116)$ & $(0.115)$ & $(0.110)$ & $(0.105)$ & $(0.230)$ & $(0.244)$ & $(0.216)$ & $(0.114)$ & $(0.220)$ & $(0.178)$ & $(0.192)$ \\
\hline \multirow{6}{*}{$\begin{array}{l}\text { Ring } \\
\text { width traits }\end{array}$} & EWP & -0.211 & 0.102 & 0.0444 & 0.0889 & 0.482 & 0.103 & -0.0338 & 0.165 & -0.249 & 0.0301 & 0.00398 \\
\hline & & $(0.233)$ & $(0.251)$ & $(0.242)$ & $(0.209)$ & $(0.0251)$ & $(0.278)$ & $(0.253)$ & $(0.242)$ & $(0.244)$ & $(0.248)$ & $(0.243)$ \\
\hline & TWP & -0.218 & -0.307 & 0.469 & -0.379 & -0.244 & -0.097 & -0.334 & -0.366 & 0.372 & -0.305 & -0.259 \\
\hline & & $(0.252)$ & $(0.251)$ & $(0.208)$ & $(0.188)$ & $(0.264)$ & $(0.297)$ & $(0.254)$ & $(0.239)$ & $(0.237)$ & $(0.238)$ & $(0.242)$ \\
\hline & LWP & 0.575 & 0.274 & 0.612 & 0.615 & -0.264 & -0.0281 & 0.544 & 0.263 & -0.118 & 0.392 & 0.376 \\
\hline & & $(0.128)$ & $(0.208)$ & $(0.144)$ & $(0.164)$ & $(0.0481)$ & $(0.253)$ & $(0.163)$ & (0.198) & $(0.236)$ & $(0.189)$ & $(0.189)$ \\
\hline
\end{tabular}


positively correlated with latewood proportion (0.392 and 0.376, respectively with $\mathrm{MOE}_{\mathrm{s}}$ and $\mathrm{MOE}_{\text {tof }}$ ).

\subsection{Genetic gain}

The genetic gains from the direct selection on three breeding objective traits (VOL, $\mathrm{MOE}_{\mathrm{S}}$ and $\mathrm{MOE}_{\text {tof }}$ ) and correlated genetic gains from the indirect selection based on other 14 growth, fiber dimension and wood quality traits are presented in Table 5 with a $10 \%$ selection intensity. There were relatively moderate genetic gains from the direct selection (e.g. $\Delta G_{M O E_{\text {tof }}}=16.0 \%, \Delta G_{V O L}=14.2 \%$ and $\Delta G_{M O E_{s}}=12.1 \%$, respectively). Relatively high correlated gains for volume are observed if selection was based on DBH and tree height. However, positive selection based on ring width proportion and wood quality traits (but lower MFA) will generate negative gains for volume except for EWP.

As expected, positive selection for growth traits generated negative gains for stiffness traits but positive selection for all ring width proportion traits, and wood quality traits (but lower MFA) generated positive gain for stiffness traits except for TWP and FTW. Indirect selection for stiffness traits based on wood quality traits had slightly smaller but still considerable gains (about 10 and $13 \%$ for $\mathrm{MOE}_{\mathrm{s}}$ and $\mathrm{MOE}_{\text {tof }}$, respectively) than the direct selection for stiffness traits. The negative genetic correlation and gains between volume and stiffness in Scots pine indicated that appropriate economic weights for growth and wood quality traits are required for balancing the gain for both volume and stiffness.

It was also observed that the indirect selection from acoustic stiffness $\left(\mathrm{MOE}_{\mathrm{tof}}\right)$ will generate more gain for clearwood stiffness $\mathrm{MOE}_{\mathrm{s}}$ than the direct selection based on $\mathrm{MOE}_{\mathrm{s}}$. This is due to the higher heritability observed in $\mathrm{MOE}_{\text {tof }}$ than in $\mathrm{MOE}_{\mathrm{s}}$ and the high genetic correlation between the two stiffness traits. Indirect selection using wood quality traits for clearwood and acoustic stiffness was also observed generating gains that were about $20 \%$ less than the gain from the direct selection for the stiffness traits.

\section{Discussion}

\subsection{Experimental design}

The completely randomized design (CRD) experiment was used for this site and other Swedish tree progeny trials in the last several decades. The potential consequence of CRD design is that residual variance could be increased due to the confounding effect of replicates and true randomly environmental errors if the significant replicates were not separated from the error term in the experiment. This would reduce heritability estimates. To overcome such potential shortage, post-blocking was usually recommended to reduce residual error variance as
Table 5 Genetic gain and correlated genetic responses for three breeding target traits with $10 \%$ selection intensity. Bold, genetic gain; normal, genetic response

\begin{tabular}{|c|c|c|c|c|}
\hline & \multicolumn{4}{|c|}{ Target traits } \\
\hline & & VOL & $\mathrm{MOE}_{\mathrm{s}}$ & $\mathrm{MOE}_{\text {to }}$ \\
\hline \multirow[t]{17}{*}{ Selection traits } & $\mathrm{DBH}$ & 13.9 & -4.91 & -4.45 \\
\hline & HGT & 10.2 & -4.60 & -3.97 \\
\hline & VOL & 14.2 & -3.56 & -2.81 \\
\hline & EWP & 3.59 & 0.241 & 0.101 \\
\hline & TWP & -0.902 & -2.36 & -2.41 \\
\hline & LWP & -7.92 & 4.27 & 5.06 \\
\hline & DEN & -7.52 & 10.7 & 13.4 \\
\hline & EWD & -6.61 & 10.6 & 13.6 \\
\hline & TWD & -2.04 & 10.1 & 12.5 \\
\hline & LWD & -2.53 & 10.0 & 13.7 \\
\hline & FRW & 1.95 & 0.921 & 0.182 \\
\hline & FTW & 2.66 & -0.801 & -3.56 \\
\hline & FWT & -6.93 & 7.95 & 12.2 \\
\hline & FMC & -1.67 & 8.64 & 9.36 \\
\hline & MFA & 3.55 & -9.12 & -10.1 \\
\hline & $\mathrm{MOE}_{\mathrm{s}}$ & -6.62 & 12.1 & 13.9 \\
\hline & $\mathrm{MOE}_{\text {tof }}$ & -4.67 & 12.46 & 16.0 \\
\hline
\end{tabular}

much as possible and to increase heritability (Ericsson 1997). The CRD was used due to its simplicity of field implementation of planting in Sweden's tree breeding program. It was estimated that the loss associated with using CRD is much less than the benefit gained by using an uncomplicated, less expensive design (Ericsson 1999). There was a continued debate within treebreeding community in Sweden whether the CRD should be used in future experiments with post-blocking or spatial analyses or using replicated and more complicated design. To answer this debated question, one study project was set up recently to compare the overall efficiency between the CRD and other replicated design using both statistical and economic measures. For this particular site in this study, the post-blocking was previously used for the analyses (Fries and Ericsson 2006, 2009), and it was found that the post-blocking was not significant. Thus, analyses based on CRD would not significantly affect the estimates of genetic variances and heritability.

There was only one site used in this study. If there was potential genotype by site ( $\mathrm{G}$ by $\mathrm{E}$ ) interaction among several sites, genetic parameters such as heritability would be inflated if estimated based on a single site. For growth traits, the $\mathrm{G}$ by $\mathrm{E}$ was found not to play a great role in Swedish Scots pine trials as long as the progeny testing was aimed at one climate region (or breeding zone) (Zhelev et al. 2003; Kroon et al. 2011). For wood quality traits such as wood density and stiffness, the $G$ by E was usually non-significant (Baltunis et al. 2010) or small (Zobel and Talbert 1984; Gapare et al. 2010) in many studies. 
These may indicate that estimate of heritability for wood quality traits would have less bias than for growth and survival traits (Eriksson 2008).

\subsection{Trait means and variation}

The average height and diameter for the trial were also measured in 2001 before the thinning. In the last 10 years, average tree height increased $5.10 \mathrm{~m}$ and DBH increased $4.25 \mathrm{~cm}$. However, both genetic and phenotypic coefficients of variation for height decreased (e.g., from 5.4 to $4.4 \%$ for $C V_{A}$ and from 11.3 to $8.3 \%$ for $\mathrm{CVp}$ for tree height) (Fries and Ericsson 2006, 2009; Kroon et al. 2008). The reduction of both $C V_{A}$ and $\mathrm{CVp}$ may be caused by the thinning process that removed smaller depressed trees unproportionally.

The average value of whole core wood density $\left(447 \mathrm{~kg} / \mathrm{m}^{3}\right)$ was comparable with the average densities reported in other Scots pine studies. The separation of earlywood density $\left(331 \mathrm{~kg} / \mathrm{m}^{3}\right)$ and latewood density $\left(763 \mathrm{~kg} / \mathrm{m}^{3}\right)$ using a transition wood made the difference of wood density between the earlywood and latewood larger than the previous comparison between the earlywood and latewood when the delineation of a transition zone was not implemented (Fries and Ericsson 2006, 2009). The proportion of the latewood was recognized as one of the most important factors influencing the whole core density (Louzada and Fonseca 2002). Also, the latewood proportion is usually increased as cambial age increases, with a consequence of an increased overall wood density. Wood stiffness is one of the most important properties of structural wood products, and Scots pine is known for its strong, stiff and dense wood. Mean values for $\mathrm{MOE}_{\mathrm{s}}$ and $\mathrm{MOE}_{\text {tof }}$ were 10.2 and $6.68 \mathrm{Gpa}$, respectively. The difference between these two estimates was due to the different methods used for the measurements. SilviScan is calibrated using sonic resonance on dry wood and acoustic dynamic measurement used on green wood, and green wood is less stiff than the dry wood. Such difference was observed in radiata pine (Pinus radiata) (Gapare et al. 2009), Douglas fir (Pseudotsuga menziesii) (Lachenbruch et al. 2010) and loblolly pine (Pinus taeda) (Isik et al. 2011).

\subsection{Genetic variation and heritability}

The coefficient of additive genetic variation $\left(C V_{A}\right)$ for density was about $4 \%$ which was similar to the previous estimates of $C V_{A}$ in Scots pine (Ericsson and Fries 2004; Fries and Ericsson 2006, 2009 and Fries 2012). $C V_{A}$ for MFA, $\mathrm{MOE}_{\mathrm{s}}$ and $\mathrm{MOE}_{\text {tof }}$ was $12.5,11.1$ and $13.6 \%$, which were about three times of the estimates for density. Much higher $C V_{A}$ for MOE than wood density indicate that there will be more scope for improving MOE than for its component trait of wood density. Higher $C V_{A}$ for MOE than for wood density was also found in radiata pine (Gapare et al. 2009) and Norway spruce (Gräns et al. 2009).

Heritability is an important parameter in the prediction of genetic gain and for developing breeding strategies (Falconer and Mackay 1996). Heritability for density, stiffness and fiber dimension traits in this study was moderate, generally around or above 0.4 , while heritability for growth traits, proportions of earlywood, transition wood and latewood types was lower $(0.147-0.306)$. The heritability for growth traits and wood density was similar to the previous estimates in Scots pine (Ericsson and Fries 2004; Fries and Ericsson 2006, 2009; Kroon et al. 2008) and black (Picea mariana), white (Picea glauca) (Lenz et al. 2010, 2011) and Norway spruce (Hylen 1999; Park et al. 2012; Zhang and Jiang 1998) and maritime pine (Pinus pinaster) (Louzada and Fonseca 2002). Relative higher genetic variation $\left(C V_{A}=7.25 \%\right)$, moderate heritability $\left(h^{2}=0.306\right)$ and lower mean value $(15.3 \%)$ for the latewood percentage were interesting observations. The latewood percentage was also highly correlated with whole core density and stiffness. Therefore, improvement of latewood percentage seems highly desirable and potential for improving overall wood density and stiffness of Scots pine (Gryc et al. 2011).

The low heritability for MFA in this study $\left(h^{2}=0.264\right)$ is comparable with the estimates in Norway spruce (around 0.30 , Hannrup et al. 2004) but lower than in radiata pine (average $h^{2}=0.63$, Wu et al. 2008). Higher MOE increases the recovery rate of the structural and appearance grade products, which give a higher economic return. MOE was under moderate genetic control with heritability around 0.4 in this study. This was higher than for Douglas fir $\left(h^{2}=0.33\right.$, Vikram et al. 2011) and loblolly pine $\left(h^{2}=0.30\right.$, Isik et al. 2011) but lower than in radiata pine (average $h^{2}=0.50$, Wu et al. 2008).

\subsection{Genetic correlations between traits}

Generally, genetic correlations among the growth traits and among the wood quality traits are favorable, but genetic correlations between the growth and wood quality traits are unfavorable in Scots pine. The negative correlation between growth traits and wood quality traits could be genetic cause or environmental causes (Auty and Achim 2008; Louzada and Fonseca 2002; Lenz et al. 2013). Highly unfavorable genetic correlation between DBH and whole core density $(-0.479)$, clearwood MOE $(-0.506)$ and dynamic acoustic MOE $(-0.382)$ was observed in this study. Such adverse genetic correlations between growth and wood quality traits were observed in a previous Scots pine study (Fries and Ericsson 2009) and in many other conifers (Wu et al. 2008).

In advanced generation tree breeding programs, tree breeders are becoming increasingly concerned with the negative genetic correlation between growth and wood quality traits (Wu and Sanchez 2011). Stiffness is usually a breeding objective trait to increase recovery rate for sawn timber, and 
the negative genetic correlation between growth traits and stiffness (MOE) indicates proper economic values that should be estimated in the future (Ivković et al. 2006).

\subsection{Genetic gains}

Genetic gain is often used as a measure of the increase in performance after direct or indirect selection. Tree volume was one of the most important selection criteria in the Swedish Scots pine breeding program (Fries 2012). Direct selection for volume had the highest genetic gain of $14.2 \%$. Selection based on DBH and height also had high genetic gain (13.9 and $10.2 \%$, respectively for volume), but selection for volume, DBH and height generated negative genetic gain for stiffness. Similarly, selection based on stiffness and wood density traits produced negative gain for volume. The negative correlated response between growth, and wood density traits were obvious in previous studies of Scots pine (Fries 2012; Hannrup et al. 2000) and other pines and spruces (Gräns et al. 2009; Wu et al. 2008). For sawn timber of Scots pine should $4.4-4.9 \%$ of the stiffness be lost if selection was based on DBH alone. Such negative genetic gain reinforces that multiple trait selection using optimal economic weights (Ivković et al. 2006) and optimal breeding strategies (Wu and Sanchez 2011) is recommended for the advanced Scots pine and other conifer breeding programs.

Acknowledgments We acknowledge the assistance in field sampling by Henrik Hallingbäck, David Hall and Mr Zhiqiang Chen and sample preparation by Valentina Floran and Ann Sehlstedt. SilviScan services were provided by Sven-Olof Lundqvist from Innventia, and Bengt Andersson from Skogforsk provided advices on the project and the access of the experiment.

Funding The project was funded by grants from Kempestiftelserna and Föreningen Skogsträdsförädling foundation. Institutional support from the Swedish University of Agriculture Sciences and in-kind support from Skogforsk and Innventia are greatly acknowledged.

\section{References}

Auty D, Achim A (2008) The relationship between standing tree acoustic assessment and timber quality in Scots pine and the practical implications for assessing timber quality from naturally regenerated stands. Forestry 81:475-487. doi:10.1093/forestry/cpn015

Baltunis BS, Wu HX, Powell MB (2007) Inheritance of density, microfibril angle, and modulus of elasticity in juvenile wood of Pinus radiata at two locations in Australia. Can J For Res 37:2164-2174

Baltunis BS, Gapare WG, Wu HX (2010) Genetic parameters and genotype by environment interaction in radiata pine for growth and wood quality traits in Australia. Silvae Genet 59:113-124

Berlin M (2009) Development of economic forest tree breeding objectives. PhD Thesis. Acta Universitatis Agriculturae Sueciae - Agraria, 2009:90. Uppsala Sweden, p 88

Brandel G (1990) Volume functions for individual trees. Scots pine (Pinus sylvestris), Norway spruce (Picea abies) and birch (Betula pendula \& Betula pubescens). Swedish University of Agricultural Sciences. Department of Forest Yield Research. Report 26: 183 p. ISSN 0348-7636. (In Swedish with English summary)

Bucur V (2006) Acoustics of Wood, 2nd edn. SpringerVerlag, Berlin

Cave ID (1976) Modelling the structure of the softwood cell wall for computation of mechanical properties. Wood Sci Technol 10:19-28. doi:10.1007/BF00376381

Evans R (2006) Wood stiffness by x-ray diffractometry, in "Characterization of the Cellulosic, Cell Wall". In: Stokke D, Groom LH (eds) Characteristics of the Cellulosic Cell Wall, Southern Research Station, Iowa State University, Colorado, US. Blackwell Publishing, pp 138-146

Eriksson G (2008) Pinus sylvestris: Recent Genetic Research. Department of Plant Biology and Forest Genetics, Genetic Center, SLU, Box 7080, SE 75007 Uppsala, Sweden, pp 111

Ericsson T (1997) Enhanced heritabilities and best linear unbiased predictors through appropriate blocking of progeny trials. Can J For Res 27:2097-2101. doi:10.1139/x97-153

Ericsson T (1999) Reply — enhanced heritabilities and best linear unbiased predictors through appropriate blocking of progeny trials. Can J For Res 29:1635-1636. doi:10.1139/x99-156

Ericsson T, Fries A (2004) Genetic analysis of fiber size in a full-sib Pinus sylvestris $L$. progeny test. Scand. J. Forest Res 19:7-14. doi:10. 1080/02827580310019031

Falconer DS, Mackay TFC (1996) Introduction to quantitative genetics, 4th edn. Longman Group Ltd, Harlow

Fries A, Ericsson T (2006) Estimating genetic parameters for wood density of Scots pine (Pinus sylvestris L.). Silvae Genet 55:84 92

Fries A, Ericsson T (2009) Genetic parameters for earlywood and latewood densities and development by increasing age in Scots pine. Ann For Sci 66:404. doi:10.1051/forest/2009019

Fries A (2012) Genetic parameters, genetic gain and correlated responses in growth, fiber dimensions and wood density in a Scots pine breeding population. Ann For Sci 69:783-794. doi:10.1007/ s13595-012-0202-7

Gapare WJ, Baltunis BS, Ivković M, Wu HX (2009) Genetic correlations among juvenile wood quality and growth traits and implications for selection strategy in Pinus radiata D. Don Ann For Sci 66:606-611. doi:10.1051/forest/2009044

Gapare WJ, Ivković M, Baltunis BS, Matheson CA, Wu HX (2010) Genetic stability of wood density in Pinus radiata D. Don plantation estate across Australia. Tree Genet Genomes 6:113-125

Gilmour AR, Gogel BJ, Cullis BR Thomson R (2009) ASReml User Guide release 3.0. VSN-International Ltd. Hemel Hempstead, UK

Gräns D, Hannrup B, Isik F, Lundqvist SO, McKeand S (2009) Genetic variation and relationships to growth traits for microfibril angle, wood density and modulus of elasticity in a Picea abies clonal trial in southern Sweden. Scand J Forest Res 24:494-503. doi:10.1080/ 02827580903280061

Gryc V, Vavrčík H, Horn K (2011) Density of juvenile and mature wood of selected coniferous species. J For Sci 57:123-130

Haapanen M, Velling P, Annala MJ (1997) Progeny trial estimates of genetic parameters for growth and quality traits in Scots pine. Silva Fenn 31:3-12

Hannrup B, Ekberg I (1998) Age-age correlations for tracheid length and wood density in Pinus sylvestris. Can J For Res 28:1373-1379. doi: 10.1139/cjfr-28-9-1373

Hannrup B, Cahalan C, Chantre G, Grabner M, Karlsson B, Le Bayon I, Jones GL, Muller U, Pereira H, Rodrigues JC, Rosner S, Rozenberg P, Wilhelmsson L, Wimmer R (2004) Genetic parameters of growth and wood quality traits in Picea abies. Scand J For Res 19:14-29. doi:10.1080/02827580310019536

Hannrup B, Ekberg I, Persson A (2000) Genetic correlations among wood, growth capacity and stem traits in Pinus sylvestris. Scand J Forest Res 15:161-170. doi:10.1080/028275800750014966 
Hannrup B, Danell Ö, Ekberg I, Moëll M (2001) Relationships between wood density and tracheid dimensions in Pinus sylvestris L. Wood Fiber Sci 33:173-181

Hallingbäck H (2010) Genetic improvement of shape stability in Norway spruce and Scots pine sawn timber. Acta Universitatis Agriculture Sueciae-Agraria 2010:22. Uppsala, Sweden, pp 102

Hylen G (1999) Age trends in genetic parameters of wood density in young Norway spruce. Can J For Res 29:135-143. doi:10.1139/cjfr29-1-135

Isik F, Mora CR, Schimleck LR (2011) Genetic variation in Pinus taeda wood properties predicted using non-destructive techniques. Ann For Sci 68:283-293. doi:10.1007/s13595-011-0035-9

Ivković M, Wu HX, McRae TA, Powell MB (2006) Developing breeding objectives for radiata pine structural wood production I. Bioeconomic model and economic weights. Can J For Res 36: 2920-2931. doi:10.1139/x06-161

Kroon J, Andersson B, Mullin TJ (2008) Genetic variation in the diameter-height relationship in Scots pine (Pinus sylvestris). Can J For Res 38:1493-1503. doi:10.1139/X07-233

Kroon J, Ericsson T, Jansson G, Andersson B (2011) Patterns of genetic parameters for height in field genetic tests of Picea abies and Pinus sylvestris in Sweden. Tree Genet Genomes 7:1099-1111. doi:10. 1007/s11295-011-0398-y

Lachenbruch B, Johnson GR, Downes GM, Evans R (2010) Relationships of density, microfibril angle, and sound velocity with stiffness and strength in mature wood of Douglas-fir. Can J For Res 40:55-64. doi:10.1139/X09-174

Lenz P, Coloutier A, MacKay J, Beaulieu J (2010) Genetic control of wood properties in Picea glauca — an analysis of trends with cambial age. Can J For Res 40:703-715. doi:10.1139/X10-014

Lenz P, MacKay J, Rainville A, Cloutier A, Beaulieu J (2011) The influence of cambial age on breeding for wood properties in Picea glauca. Tree Genet Genomes 7:641-653. doi:10.1007/s11295-011-0364-8

Lenz P, Auty D, Achim A, Beaulieu J, MacKay J (2013) Genetic improvement of white spruce mechanical wood traits - early screening by means of acoustic velocity. Forests 4:575-594. doi:10.3390/f4030575
Louzada JLPC, Fonseca FMA (2002) The heritability of wood density components in Pinus pinaster Ait. and the implications for tree breeding. Ann For Sci 59:867-873. doi:10.1051/forest:2002085

Park YS, Weng YH, Mansfield SD (2012) Genetic effects on wood quality traits of plantation-grown white spruce (Picea glauca) and their relationships with growth. Tree Genet Genomes 8:303-311. doi:10.1007/s11295-011-0441-z

Rosvall O (ed) (2011) Review of the Swedish tree breeding programme. Arbetsrapport, Skogforsk, Uppsala Science Park, Uppsala. pp 114

Sokal RR, Rohlf FJ (1995) Biometry: the principles and practice of statistics in biological research, 3rd edn. W.H. Freeman, New York

Velling P (1974) Phenotypic and genetic variation in the wood basic density of Scots pine (Pinus sylvestris. L.). Folia Forestalia 188. Finnish Forest Research Institute. Helsinki. (In Finnish with English summary), pp 1-29

Vikram V, Cherry ML, Briggs D, Cress DW, Evans R, Howe GT (2011) Stiffness of Douglas-fir lumber: effects of wood properties and genetics. Can J For Res 41:1160-1173. doi:10.1139/x11039

Wu HX, Ivković M, Gapare WJ, Matheson AC, Baltunis BS, Powell MB, McRae TA (2008) Breeding for wood quality and profit in Pinus radiata: a review of genetic parameter estimates and implications for breeding and deployment. N Z J For Sci 38:56-87

Wu HX, Sanchez L (2011) Effect of selection method on genetic correlation and gain in a two trait selection scheme. Aust For 74:36-42. doi:10.1080/00049158.2011.10676344

York HH, Littlefield EW (1942) The naturalization of Scotch pine, northeastern Oneida County, New York. J For 40:552-559

Zhang SY, Jiang ZH (1998) Variability of selected wood characteristics in 40 half-sib families of black spruce (Picea mariana). Wood Sci Technol 32:71-82. doi:10.1007/BF00702561

Zhelev P, Ekberg I, Eriksson G, Norell L (2003) Genotype environment interactions in four full-sib progeny trials of Pinus sylvestris (L.) with varying site indices. For Genet 10:93-102

Zobel B, Talbert J (1984) Applied forest tree improvement. John Wiley \& Sons, New York, pp 505 